\title{
Importance Ranking of Accident Factors of Construction Tower Crane by AHP Technique
}

\author{
Ju-Yong Kim¹, Gwawng-Hee Kim² \\ ${ }^{1}$ Department of Architectural Engineering, Graduate School, Kyonggi University, Suwon, South Korea \\ ${ }^{2}$ Department of Architectural Engineering, Kyonggi University, Suwon, South Korea \\ Email: ^ghkim@kyonggi.ac.kr
}

How to cite this paper: Kim, J.-Y. and Kim, G.-H. (2020) Importance Ranking of Accident Factors of Construction Tower Crane by AHP Technique. Journal of Building Construction and Planning Research, 8, 237-244.

https://doi.org/10.4236/jbcpr.2020.84015

Received: November 9, 2020

Accepted: December 5, 2020

Published: December 8, 2020

Copyright $\odot 2020$ by author(s) and Scientific Research Publishing Inc. This work is licensed under the Creative Commons Attribution International License (CC BY 4.0).

http://creativecommons.org/licenses/by/4.0/

\begin{abstract}
In Korea construction industry, the increase of tower crane's usage continuously and the accidents of tower crane are increasing simultaneously. But research on tower crane is insufficient for reducing the tower crane accident. This study aims to derive the importance ranking of accident factors of cab-control tower crane by AHP analysis. AHP survey was conducted on experts such as construction engineer, construction manager, safety engineer, and tower crane operator, who have more than 10-year career. The results of AHP analysis reveal that top ranking factor of cab-control tower crane's accident is erection work. Therefore, the derived factors should be managed, and the priority measures taken for reducing the tower crane accidents according to the ranking of accident factors.
\end{abstract}

\section{Keywords}

Cab-Control Tower Crane, Analytic Hierarchy Process, Importance Ranking of Accident Factors

\section{Introduction}

The use of tower crane in construction sites has constantly increased since its first introduction in the 1980's. According to statistics on the construction machinery status of the Ministry of Land, Infrastructure and Transport, in 2015, Korea had 3408 cab-control tower cranes (CC T/C). The number of tower cranes increased to $4385 \mathrm{CC}$ T/C by 22 percent in 2019 [1]. Consequently, as the number of tower crane used in construction site has increased steadily, there are potential accident factors of tower crane itself. That is, tower crane is dangerous and their various risk factors are inherent in the erection, lifting, and dismantling works [2]. Every year, the number of tower crane-related accidents in con- 
struction sites continues to increase. The occurrence of serious accidents regarding tower crane is 9 cases in 2016, 7 cases in 2017, 6 cases in 2018, and 8 cases in 2019 [3].

The government has made various efforts to reduce tower crane-related disasters. For example, the government revised the enforcement regulations of the Construction Equipment Management Act from October 2019 in order to prevent the occurrence of tower crane accidents [3]. In addition, academia has conducted research on various factors of accidents by analyzing tower crane accident case, etc. [4] [5] [6] for reducing tower crane-related disasters. The CC $\mathrm{T} / \mathrm{C}$ is that equipment aging, insufficient work management, violation of work guidelines and safety rules, and lack of communication were the main causes of accidents [7]. Despite these efforts, it was not enough to prevent continuously CC T/C accidents. Therefore, this study aimed to identify the risk factors and then the importance factors of $\mathrm{CC} \mathrm{T} / \mathrm{C}$ to derive the importance ranking.

In this study, AHP technique was adapted to derive the importance of each tower crane accident factor, for it is an effective way to prioritize the responses based on the experience of experts working in the construction site. The AHP survey has been conducted on the construction engineers, construction managers, safety managers, and tower crane operators that are expert of tower crane related experience for more than 10 years. The process of this study is as follows: Firstly, literature review was conducted such as accident factor of previous study and tower crane configuration, etc. Secondly, preliminary survey has been carried out to select the factors of tower crane accidents while the questions for the survey are drawn from literature review. The selected factors have been used in AHP questionnaire. Analytic Hierarchy Process (AHP) is a decision-making structured technique developed by T. Saaty in the early 1970s, reflecting the knowledge, experience, and intuition of respondents in pair-wise comparisons through the elements of the hierarchy of decision-making [8]. Thirdly, AHP analysis was performed. The importance of accident factors has been analyzed through AHP survey conducted on the construction engineers, construction managers, safety managers, and tower crane operators with more than 10 years of field experience. Fourthly, the importance of tower crane accidents was made ranking to prevent any accidents of tower crane.

\section{Literature Review}

\subsection{Previous Research}

Various studies related to the safety accidents of tower crane. The studies are shown in Table 1. Several studies related to tower crane accidents have been

Table 1. Literature review related to tower crane accidents.

\begin{tabular}{cl}
\hline Author & \multicolumn{1}{c}{ Major research subject } \\
\hline Aneziris et al. (2008) [9] & $\begin{array}{l}\text { Risk analysis of the results of tower crane accidents using WORM } \\
\text { (Workgroup Occupational Risk Model) }\end{array}$
\end{tabular}




\section{Continued}

\begin{tabular}{ll}
\hline Kwon (2015) [10] & $\begin{array}{l}\text { Suggest priority management targets through analysis using the tower } \\
\text { crane accidents status and FMEA technique by types }\end{array}$ \\
Richard et al. (2001) [1]] & $\begin{array}{l}\text { Suggest a plan to prevent safety accidents by analyzing cases of tower } \\
\text { crane safety accidents and safety procedures }\end{array}$ \\
Aviad et al. (2009) [12] & $\begin{array}{l}\text { Propose the safety management plans through analysis using the } \\
\text { importance and priority of each accident factor through AHP analysis }\end{array}$ \\
Cho (2017) [7] & $\begin{array}{l}\text { Safety management data derived through analysis using the importance } \\
\text { and priority of each accident factor through AHP analysis }\end{array}$ \\
Song (2018) [13] & $\begin{array}{l}\text { Present the measures to improve safety management by identifying and } \\
\text { analyzing types of accidents using tower crane major disaster case } \\
\text { analysis and survey }\end{array}$ \\
\hline
\end{tabular}

conducted, but previous studies have mainly focused on the derivation of accident factors and tower crane management plans. That is, there are not enough studies that can be used for the management of tower crane accident by ranking the importance of accident factors.

\subsection{Accident Factors of Tower Crane Presented in Previous Study}

Until nowadays, various previous studies on the accidents factors of tower crane have been in progress, and the factors suggested in previous studies are shown in Table 2.

\section{AHP Model of Tower Crane Accident Factors}

\subsection{Selected Accident Factors}

For level 1 of AHP model, the 11 accident factors were selected from previous study as shown in Table 3. The 5-factors of level 2 such as dismantling work, lifting work, erection work, management factor and T/C machine factor were selected by interviewing with experts, who have more than 10 years of field experience, from 11 accident factors. The 25 factors extracted from previous studies for level 2 of AHP model were classified into the level 1 factors. Table 4 shows the accident factors assigned to the level 1 and level 2 of AHP model.

\subsection{AHP Survey}

As shown in Table 5, AHP analysis has been conducted on that a total of 44 surveys carried out on the experts with more than 10 years of experience. The survey respondents were 14 construction engineers, and the other respondents were 10 each. In addition, $43 \%$ of all respondents have more than 20 years of experience. The survey was conducted from March to May 2020, and a 9-point scale was used in the questionnaire to quantify in pairwise comparisons between factors.

\section{The Results of AHP Survey}

As the result of an AHP survey conducted among 14 construction engineers on 
Table 2. Extracting accident factors of tower crane's accident in previous study.

\begin{tabular}{cl}
\hline Kwon (2015) & Lifting work/Erection work/Dismantling work/Climb work/Others work \\
Choi (2017) & $\begin{array}{l}\text { Machine factor/Management factor/Erection·Dismantling.Climb } \\
\text { factor/Operation factor }\end{array}$ \\
Song (2018) & Erection work/Climbing work/Dismantling work/Common \\
Kim (2018) & Erection work/Climb work/Tower carne operation \\
\hline
\end{tabular}

Table 3. Extracting accident factors of tower crane's accident by preliminary survey.

\begin{tabular}{ll}
\hline Lxtracted factors & On-site conditions/Process and construction period/Machine factor/ \\
& Management factor/Tower carne operation/Other \\
\hline
\end{tabular}

Table 4. Second level factors of AHP structure.

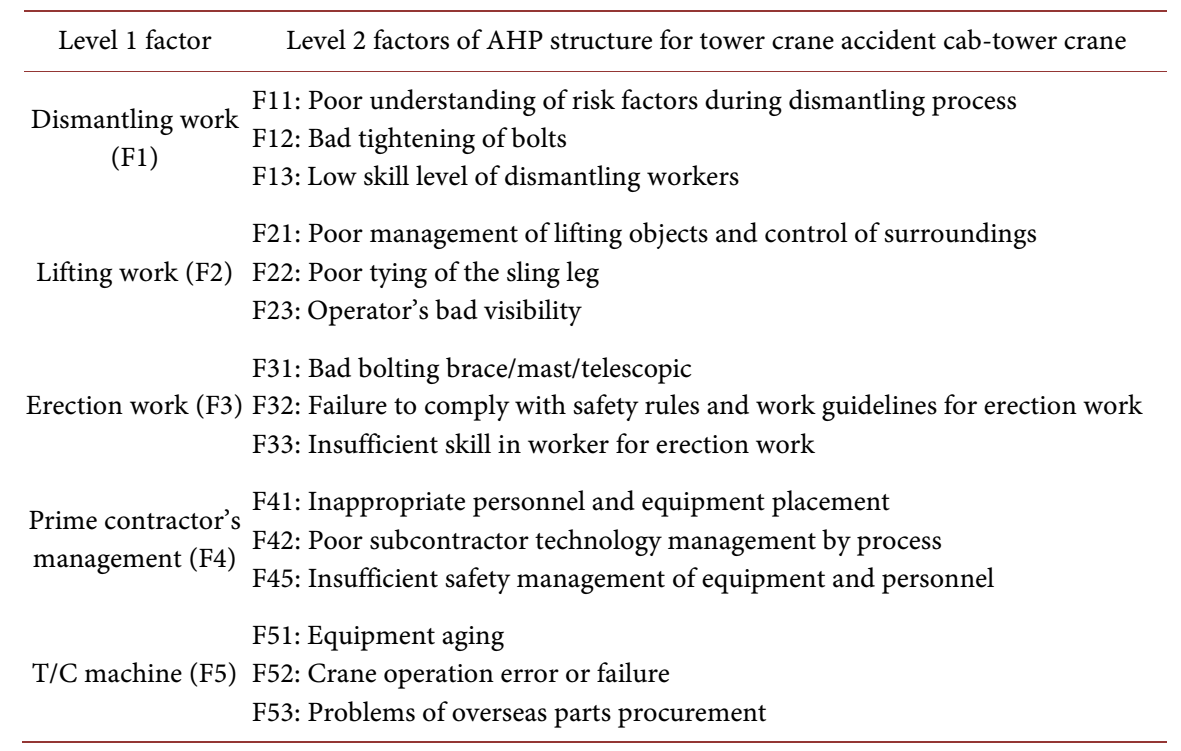

Table 5. AHP questionnaire respondents.

\begin{tabular}{lccc}
\hline & Distribution & Frequency (person) & $(\%)$ \\
\hline \multirow{3}{*}{ Profession } & Construction engineer & 14 & 31 \\
& Construction manager & 10 & 23 \\
& Safety engineer & 10 & 23 \\
Careers & Tower crane operator & 10 & 23 \\
& 10 years - 20 years & 25 & 57 \\
& More than 20 years & 19 & 43 \\
\hline
\end{tabular}

the top rank factors of tower crane accidents, the dismantling work was the most important factor at 0.391 followed by lifting work 0.294 , erection work 0.156 , prime contractor's management 0.087 . The $\mathrm{T} / \mathrm{C}$ machine factor was the lowest at 0.072. The results of survey from construction managers, safety managers, and tower crane operators are shown in Table 6. As the results of the experts' responses 
Table 6. Importance ranking of level 1 factors of AHP model.

\begin{tabular}{|c|c|c|c|c|c|c|c|c|c|c|}
\hline \multirow{2}{*}{ Level 1 factor } & \multicolumn{2}{|c|}{ Construction engineer } & \multicolumn{2}{|c|}{ Construction manager } & \multicolumn{2}{|c|}{ Safety engineer } & \multicolumn{2}{|c|}{ Tower crane operator } & \multicolumn{2}{|c|}{ Total } \\
\hline & $\mathrm{Wt}$ & Rank & $\mathrm{Wt}$ & Rank & Wt & Rank & Wt & Rank & $\mathrm{Wt}$ & Rank \\
\hline Dismantling work & 0.391 & 1 & 0.090 & 5 & 0.100 & 5 & 0.099 & 5 & 0.170 & 5 \\
\hline Lifting work & 0.294 & 2 & 0.293 & 1 & 0.121 & 4 & 0.146 & 4 & 0.214 & 3 \\
\hline Erection work & 0.156 & 3 & 0.205 & 3 & 0.219 & 3 & 0.322 & 1 & 0.226 & 1 \\
\hline Prime contractor's management & 0.087 & 4 & 0.164 & 4 & 0.254 & 2 & 0.194 & 3 & 0.175 & 4 \\
\hline $\mathrm{T} / \mathrm{C}$ machine & 0.072 & 5 & 0.248 & 2 & 0.305 & 1 & 0.239 & 2 & 0.216 & 2 \\
\hline
\end{tabular}

summarized from the AHP survey, erection work was the 1st rank factor at 0.226 followed by $\mathrm{T} / \mathrm{C}$ operator 0.216 , lifting work 0.214 , prime contractor's management 0.175 while dismantling work was the lowest at 0.170 .

As the result of AHP survey conducted among construction engineers on the safety accident factors regarding level 2 of AHP model, the importance for poor understanding of risk factors during dismantling process was the 1st rank followed by operator's bad visibility and low skill level of dismantling workers. The results of AHP analysis on the level 2 accident factors of construction managers, safety managers, and tower crane operators are as shown in Table 7.

The importance values were collected from the opinions of the experts on safety accident factors regarding tower cranes. The factors regarding CC T/C appeared important in the order they were listed as follows; operator's bad visibility, bad bolting brace/mast/telescopic, poor subcontracting technology management by process failure to comply with safety rules and work guidelines for installation work, problems of overseas parts procurement, and poor understanding of risk factors during dismantling process.

\section{Discussion and Conclusions}

Despite the efforts of each field to reduce accidents regarding tower cranes, serious disasters are not decreasing. In addition, as the usage of tower cranes continues to increase, the number of accidents is increasing. This study has been conducted to prevent tower crane-related accidents by deriving the risk factors of CC T/C the importance of each factor to be used as a reference. As the analysis result of the 1st level (the accident weight) of AHP model, the accident factor weight of erection of the tower crane is largest, followed by the T/C machine.

The final ranking of tower crane accidents was derived by multiplying the weight of the 1st level and the weight of the 2nd level. As its result, the final ranking of accident factors was F23 (Operator's bad visibility), F31 (Bad bolting brace/mast/telescopic), F42 (Poor subcontractor technology management by process), F53 (Problems of overseas parts procurement) in order. The operator's visibility of the location where is target object and the surrounding conditions are more important than any other factors. If the operator has no visibility, the operator simply has to rely on the hand signal or the radio sound from other 
Table 7. Importance ranking of tower crane's accident factors.

\begin{tabular}{|c|c|c|c|c|c|c|c|c|c|c|c|}
\hline \multirow{2}{*}{$\begin{array}{l}\text { First } \\
\text { Level }\end{array}$} & \multirow{2}{*}{$\begin{array}{l}\text { Second level } \\
\text { (sub factor). }\end{array}$} & \multicolumn{2}{|c|}{$\begin{array}{l}\text { Construction } \\
\text { engineer }\end{array}$} & \multicolumn{2}{|c|}{$\begin{array}{c}\text { Construction } \\
\text { manager }\end{array}$} & \multicolumn{2}{|c|}{ Safety engineer } & \multicolumn{2}{|c|}{$\begin{array}{c}\text { Tower crane } \\
\text { operator }\end{array}$} & \multicolumn{2}{|c|}{ Total } \\
\hline & & $\mathrm{Wt}$ & $\mathrm{R}$ & $\mathrm{Wt}$ & $\mathrm{R}$ & $\mathrm{Wt}$ & $\mathrm{R}$ & $\mathrm{Wt}$ & $\mathrm{R}$ & $\mathrm{Wt}$ & $\mathrm{R}$ \\
\hline \multirow{3}{*}{ F1 } & F11 & 0.204 & 1 & 0.039 & 10 & 0.028 & 12 & 0.048 & 8 & 0.073 & 6 \\
\hline & F12 & 0.066 & 6 & 0.030 & 13 & 0.052 & 10 & 0.011 & 15 & 0.048 & 12 \\
\hline & F13 & 0.121 & 3 & 0.021 & 15 & 0.020 & 13 & 0.040 & 10 & 0.049 & 11 \\
\hline \multirow{3}{*}{$\mathrm{F} 2$} & F 21 & 0.042 & 8 & 0.117 & 4 & 0.015 & 14 & 0.096 & 4 & 0.071 & 8 \\
\hline & F22 & 0.107 & 4 & 0.041 & 9 & 0.012 & 15 & 0.011 & 14 & 0.037 & 15 \\
\hline & F23 & 0.144 & 2 & 0.135 & 1 & 0.093 & 4 & 0.039 & 11 & 0.107 & 1 \\
\hline \multirow{3}{*}{ F3 } & F31 & 0.081 & 5 & 0.122 & 2 & 0.126 & 2 & 0.116 & 3 & 0.098 & 2 \\
\hline & F32 & 0.040 & 9 & 0.057 & 7 & 0.054 & 9 & 0.180 & 1 & 0.080 & 4 \\
\hline & F33 & 0.036 & 10 & 0.027 & 14 & 0.040 & 11 & 0.085 & 6 & 0.046 & 13 \\
\hline \multirow{3}{*}{ F4 } & F41 & 0.018 & 14 & 0.039 & 11 & 0.067 & 7 & 0.044 & 9 & 0.042 & 14 \\
\hline & $\mathrm{F} 42$ & 0.047 & 7 & 0.036 & 12 & 0.123 & 3 & 0.131 & 2 & 0.084 & 3 \\
\hline & $\mathrm{F} 43$ & 0.022 & 13 & 0.089 & 5 & 0.064 & 8 & 0.019 & 13 & 0.050 & 10 \\
\hline \multirow{3}{*}{ F5 } & F51 & 0.023 & 12 & 0.119 & 3 & 0.079 & 5 & 0.079 & 7 & 0.064 & 9 \\
\hline & F52 & 0.018 & 15 & 0.083 & 6 & 0.075 & 6 & 0.026 & 12 & 0.071 & 7 \\
\hline & F53 & 0.031 & 11 & 0.047 & 8 & 0.152 & 1 & 0.090 & 5 & 0.075 & 5 \\
\hline
\end{tabular}

workers. These problems are difficult for the related managers such as safety managers to accurately judge, and because they have no choice but to rely on the judgment of the tower crane operator, it is necessary to attach a high-performance camera to the trolley of tower crane. The problems of F31 (Bad bolting brace/mast/telescopic) and F42 (Poor subcontracting technology management by process) are related to the responsibilities and skills of the erection worker. This factor is a management problem of construction site, and it is believed that it will be possible by following the manual of erection work and improving the skills of the erection worker, so it can be solved by continuous education for the erection workers. The next factor is the quality problem of tower crane parts imported from overseas. As tower cranes have been manufactured long time ago, old parts of tower crane have been frequently replaced. Therefore, it is necessary to have a system that can guarantee the quality of parts in government. This is because tower crane renters prefer to use parts that are cheaper than the quality of parts to increase profits.

Tower crane accidents are not caused by one or two factors, but occur when several factors are being complexity and consistently. If you want not to occur of tower crane accident, not one or two accident factors is(are) be managed or removed, but several factors must be managed or removed continuously and simultaneously. Therefore, in order to reduce tower crane accidents, it would be possible if the results of this study were used to continuously manage the factors 
of tower crane accidents in construction site management. In the future, according to change of the type of tower crane used in construction site in order to reality reduce tower crane accidents in realty, it is necessary to further study the accident factors corresponding to this.

\section{Conflicts of Interest}

The authors declare no conflicts of interest regarding the publication of this paper.

\section{References}

[1] Ministry of Land, Infrastructure and Transport [Internet] (2020) Korea Statistical Information Service. http://kosis.kr

[2] Choi, C.-H. (2017) A Study on the Risk Analysis and Measures of Reduction through Tower Crane Accidents Cases. Master's Thesis, Hanyang University, Seoul.

[3] Ministry of Land, Infrastructure and Transport [Internet] (2020) Ministry of Land, Infrastructure and Transport. http://www.molit.go.kr

[4] Lee, H.-S. (2014) A Study on the Accident Analysis and the Control of Tower Cranes. Master's Thesis, Seoul National University of Science and Technology, Seoul.

[5] Choi, S.-H., Cho, K.-H., Park, D.-H. and Choi, B.-G. (2015) A Study on the Work Environment and Accident Exposure Status of Tower Crane Workers. Journal of Korea Safety Management \& Science, 17, 115-123.

http://db.koreascholar.com/article.aspx? code $=307824$ https://doi.org/10.12812/ksms.2015.17.3.115

[6] Yun, D.-H., Jong, Y.-P. and Jung, H.-K. (2019) Measures to Reduce Tower Crane Accidents during Operation by Improving Signal System and Education for Signalmen. Journal of Korea Safety Management \& Science, 34, 168-175. https://doi.org/10.23839/kabe.2019.34.2.305

[7] Cho, Y.-R. (2017) Importance Evaluation of the Safety Accident Factors of Tower Crane Using Analytic Hierarchy Process. Master's Thesis, Kyonggi University, Suwon.

[8] Cho, G.-T., Cho, Y.-G. and Kang, H.-S. (2003) The Analytic Hierarchy Process. Donghun, 1-311

[9] Aneziris, O.N., Papazoglou, I.A., Mud, M.L., Damen, M., Kuiper J., Baksteen, H., Ale, B.J., Bellamy, L.J., Hale, A.R., Bloemhoff, A., Post, J.G. and Oh, J. (2008) Towards Risk Assessment for Crane Activities. Safety Science, 46, 872-884. https://doi.org/10.1016/j.ssci.2007.11.012

[10] Kwon, O.-M. (2015) Deduction of Accident Cause for Tower-Crane Using Fmea Method. Master's Thesis, Hanyang University, Seoul.

[11] Richard, L.N., Noah, S.S. and Kyle, K.R. (2001) A Review of Crane Safety in the Construction Industry. Applied Occupational and Environmental Hygiene, 16, 1106-1117. https://www.tandfonline.com/doi/abs/10.1080/10473220127411 https://doi.org/10.1080/10473220127411

[12] Shapira, A. and Simcha, M. (2009) AHP-Based Weighting of Factors Affecting Safety on Construction Sites with Tower Cranes. Journal of Construction Engineering and Management, 135, 307-318.

https://ascelibrary.org/doi/10.1061/(ASCE)0733-9364(2009)135:4(307 
https://doi.org/10.1061/(ASCE)0733-9364(2009)135:4(307)

[13] Song, P.-Y. (2018) A Study on Improvement of Safety Management through Analysis of Tower Crane Disaster at Construction Site. Master's Thesis, Pukyong University Safety Engineering, Busan. 